F O R U M

\title{
Cone's Consistency: Reflections from a Teaching
}

\section{Assistant}

\author{
Thurman Todd Willison \\ Union Theological Seminary
}

\begin{abstract}
Beyond his academic contribution of Black Liberation Theology to the church and academy at large, James Cone should be remembered on a personal level as one who prioritized the task of teaching his students, placed the student perspective and the development of independent student voices at the center of his pedagogy, pushed his students to take classroom learning out into the world, maintained exemplary standards of consistency in his theological work and moral character, and contributed to the legacy of his home institution Union Theological Seminary in immeasurable ways. This is one of several short essays presented by recent students at a public forum at Union Theological Seminary after his death in 2018.
\end{abstract}

\section{KEYWORDS}

James Cone, Union Theological Seminary, Occupy Wall Street, systematic theology, liberation, pedagogy

The last time I spoke to Dr. James Cone in person, we were meeting in his apartment on the third floor of McGiffert Hall at Union Theological Seminary. I had met him at this location numerous times before over the course of the past five years, usually to discuss my responsibilities as his teaching assistant for his most popular course at Union, "Systematic Theology 103." On this particular occasion, I was there to request a teaching evaluation from him for future job applications. Though I noticed that Dr. Cone was completely bald for the first time since I had known him, I didn't think much of it at the time. I figured that it was quite simply a stylistic choice on his part. He looked good, and he showed no signs of ailing health. To the contrary, the vitality and sharp energy that I had come to expect from him at all times was still there in spades. I had no idea he was in the midst of his last six months on earth. As I look back on those final moments that I shared with him, it doesn't surprise me at all that he showed no sign whatsoever of a reduction in the sheer force of his charismatic personality, which from my perspective, never waivered or faltered in any of my interactions with him.

I will always look back on my experience working with Dr. Cone as his teaching assistant for four years as one of the great privileges of my life. When I reflect on the lessons I learned and the general takeaways that I received from being around him, many things come to the forefront of my mind. First and foremost, I think about the indelible impression he made upon me during my first year at Union, which was a dramatic one for the school and for New York City. Occupy Wall Street had exploded in the early months of the fall semester, and the sense of moral purpose and social activism at Union was as high as I have ever seen. Union's spirit of public engagement was fully activated and there was a level of camaraderie amongst the entire student body that I have only witnessed, to this degree, twice at Union-on this occasion and then again during the fall of 2014 in the aftermath of the Michael Brown shooting and the ensuing protests that quickly spread from Ferguson, Missouri to the 
rest of the nation. On both of these occasions, Dr. Cone was clearly visible at the forefront of the fight, and was even willing to cancel exams at one point to make space for students to pour their energies outward. His cancellation of exams turned out to be a particular effective pedagogic strategy in that it drove students to discuss the implications and outworkings of the assigned readings with more fevered attention than I had witnessed in previous semesters.

During that first year of the Occupy movement, I remember feeling that Dr. Cone was like the center of a vortex around which students' passion for racial justice and economic equality swirled. "Systematic Theology 103," which was typically at capacity with sixty to seventy incoming Union students each fall, seemed to me a strategic headquarters for allied forces heading down to Zuccotti Park as much as it was an academic class.

Interestingly, by the following spring semester, Occupy Wall Street had begun to wane, but student energy had not. It merely redirected itself away from Zuccotti Park and toward an internal controversy at Union that students had organized around. The camaraderie of the fall semester gave way to a more divisive atmosphere on campus, putting students at odds with the administration, with each other, and with some of their own professors, as lines were drawn around the issue. One person who made no bones about indicating where he stood and which side he supported was Dr. Cone. I remember watching him stand up at a crowded student lunch meeting, which packed the social hall to its gills, making it clear that he stood firmly on the side of the students and their right to make their voices heard. He was greeted with thunderous applause and a standing ovation, and I witnessed for the first time the true power of his influence upon student life and the level of sincere affection he generated in students' hearts. And from then on, no matter what the controversy or what the cause, on campus or off campus, it was abundantly clear to me that Dr. Cone would always distinguish himself as an uncompromising advocate for students. On any and every occasion, when students were lit up and fighting for change, Dr. Cone was always the loudest voice in the room and the most demonstrative when it came to his unwavering support for the student perspective and for student efforts to hold power accountable.

Indeed, his mantra, for "ST 103" and for every other class that I either took from him or participated in, was that students should focus first and foremost on finding their own, unique theological voice. I have been teaching undergraduate courses in theology, religious studies, and ethics for a few years now, and I can honestly say that I have yet to teach a class where I have not repeated this phrase: “Find your own voice!” And I always press my students to worry less about rote summary of reading material and to pour their energy more into discovering their critical stance toward that material.

To be clear, Dr. Cone was one of the most rigorous and demanding professors at Union by far. I took several seminars from him, and his reading requirements were always sizeable and the writing requirements were always challenging. Of all my readers for my comprehensive examinations, he was the one to most consistently accuse me of not having done enough primary research or reading. In a public lecture I gave on Martin Luther King, Jr., he called me out in front of the whole audience for citing too many secondary sources and not demonstrating that I had actually read King's own works (he was right and I knew it). Dr. Cone also had exacting standards for student participation, and he even called me up to his apartment one time to rebuke me for not speaking up enough in class. Whereas some of my classes felt lighter than I expected for PhD coursework, I could always count on Dr. Cone to expect the most out of me and then some. He made a point to encourage me and inspire me to become a better student, a more effective teacher, and a more productive writer. I admired this a great deal. But beyond his high expectations for academic rigor, it was also clear to me that Dr. Cone cared far more about students taking risks and finding their own theological voice than he did about them accurately summarizing the reading or giving the most exhaustive technical answers on a midterm or final. He made his theological career and reputation by taking risks, and saying things about black experience from a theological perspective that nobody else had yet dared to say. It was this kind of risk taking that he demanded without equivocation from his students, and fought like hell to compel from them. Every time I met with him to discuss my own work, he (without fail) chastised me for disguising my theological voice while also provoking me to work harder to find it. I can now sincerely say that every time I sit down to write my dissertation, I hear him sitting on my shoulder, shouting into my ear, with that infamous high-pitched tone, "Find your theological voice!"

Finally, I want to make a general remark about Dr. Cone's consistency as a teacher and as a human being. I find that many theologians I have read are often hard to pinpoint, because they have an early period, a middle period, a late period, et cetera. Though he made some adjustments throughout his career, such as using more gender inclusive language, widening his scope beyond the topic of race to a critique of economic structures, and adopting a more conciliatory tone toward race relations, Dr. Cone only ever had one theological period. His message was always the same-that the systematic oppression of black lives was anti-Christian, that the liberation and self-determination of black lives should be normative for Christian theology, and that the only way to side with God is to side with the oppressed. Dr. Cone delivered this message, book after book, lecture after 
lecture, class after class, with unfaltering conviction. He was as much a preacher for a cause as he was a teacher of a subject matter. Having studied with Dr. Cone, I now find it impossible to separate my need to adhere to high standards of academic rigor and my obligation to speak with personal theological conviction.

Dr. Cone is perhaps the only theologian I have ever known who blended his theological writings and teachings with his personal character and lifestyle to such a seamless degree that one could detect not a single discrepancy between the two. When I think of Dr. Cone, it is his conveyance of absolute conviction and moral consistency that I desire most to emulate. His legacy is his unshakeable, immoveable demeanor and fortitude, which was ever present and undiminishing. It was my honor to know him, to work for him, and to learn from him. The institution of Union Theological Seminary will certainly never be the same now that he is gone.

\section{ADDITIONAL CONTRIBUTIONS TO THE FORUM ON DR. JAMES CONE}

Editor. 2020. "Introduction to the Forum on Dr. James H. Cone as Teacher and Mentor." The Wabash Center Journal on Teaching 1(2): 79-80. https://doi.org/10.31046/wabashcenter.v1i2.1501.

\section{ABOUT THE AUTHOR}

Thurman Todd Willison is a PhD candidate in Theology and Social Ethics at Union Theological Seminary, New York City. He is currently finishing a dissertation that examines interpretations of human dignity within personalist thought, interrogating the impact of varieties of twentieth century personalism on how human dignity came to be defined in international moral discourse, and providing a constructive account of how a viable personalist theory of dignity might be theorized in light of contemporary ethical concerns. 
